\title{
PREPACI
}

For ten months in 1983 and 1984 I was a would-be revolutionary in Nicaragua. The experience taught me a lesson. As the American writer Bernard DeVoto says, "Realism is the most painful, most difficult, and slowest of human faculties."

After leaving Nicaragua with vague but creeping doubts about the Sandinista revolution, it took me several years to see the revolution for what it was. It took me another twenty years to see myself for who I was: to see why I went to Nicaragua and what happened to me while I was there.

Realism came slowly for Sandinistas, too. Sergio Ramírez was one of the revolution's top political leaders and its chief intellectual. In 1991 he wrote an essay for Granta magazine explaining why his Sandinistas had just lost the national elections. After admitting that the Sandinistas' "plans for collectivized farming seriously undermined all possibilities of winning" the allegiance of the peasants-who wanted plots of their own-Ramírez blamed the ruinous plans on his noble desire to keep the land from ever "falling back into the greediest hands." He conceded that Nicaragua's counterrevolution had become a civil war in the countryside, but he explained it by saying that the peasantry's "fears had proved stronger than our promises" and thereby split Nicaraguans into "those who understood the revolution, and those who could not be reached by it." The revolution's main failing, he seemed to be saying, was its poor sales job. Even after confessing that he and other Sandinista leaders had "been arrogant and had lost sight of important elements of political reality," 


\section{Michael Johns}

Ramírez buried the revolution's internal problems beneath his dominant story line: the mauling of a heroic little revolution in Central America by the big bad imperialist beast of the north. Less than a year after losing power, Ramírez was still too close to his revolution to see it realistically.

In fact, it took him several years to gain the distance he needed to see the revolution on its own terms and in its full complexity. It took him several years, in other words, to see that the revolution's compassion often took the form of paternalism, that its lofty goals were supported by dubious reasoning, that its good intentions excused bad policies, that its concentration of power jeopardized its democratic ideals, that its absolute faith in the goodness of its aim justified a number of heavy-handed means to bring it about. In the end, Ramírez broke with what remained of the Sandinistas. He called his memoir of the revolution Adiós muchachos (So long, boys).

Gioconda Belli's memoir is called The Country under My Skin. Beginning as early as 1984, says the former Sandinista, "the Revolution slowly lost its steam, its spark, its positive energy, to be replaced by an unprincipled, manipulative, and populist mentality ... we were feeling more and more like spectators to a process that continued to live off its heroic, idealistic image even though, in practice, it was being gutted and turned into an amorphous, arbitrary mess." Belli might have been feeling like a spectator to a wayward revolution, but she did not quite know it: she remained a revolutionary until the Sandinistas were voted out of office.

While Ramírez and Belli tell brave and searching stories from deep inside the revolution, neither tells the story that I want to tell: how the ideal of socialism-a political ideal that requires almost complete moral and intellectual certaintybreaks down under the pressure of realism. It is a story, in other words, about how much truth one can see of a socialist revolution and still believe in it.

I'm no Voltaire, but as a twenty-four-year-old in Nicara- 
gua I was something like Voltaire's Candide-in the sense that I too was "a young metaphysician entirely unschooled in the ways of the world." And like Candide, I needed many countervailing experiences before finally tempering my enthusiasm for Marx's version of Pangloss's theory that every effect has a direct cause in a chain of necessity leading to the best of ends. A grand theory makes life clear and simple. It provides a sense of control and purpose. It gives you an identity. It even charts your course of action. So it's very hard to give up.

And the difficulty with describing how I did give it up is that, like Candide, I had only the faintest idea that I was losing my faith. I fought a fierce mental battle in Nicaragua about the Sandinista revolution, but I fought it almost entirely in the back of my mind. So I describe the battle through a series of incidents that, without my quite knowing it, were chipping away at my political certainty while eroding my selfimage as an American revolutionary working for socialism in Nicaragua.

Realism does not mean seeing things as they really are. Truth is elusive, especially in politics. Realism means thinking realistically. At its simplest, thinking realistically means allowing yourself to see what George Orwell called "uncomfortable" facts - uncomfortable because they confound your view of the world and your place in it. That is why DeVoto said realism is painful, difficult, and slow. And it is why someone as smart as Charles Darwin had to force himself to follow what he called, in his autobiography, "a golden rule, namely, that whenever a published fact, a new observation or thought came across me, which was opposed to my general results, to make a memorandum of it without fail and at once; for I had found by experience that such facts and thoughts were far more apt to escape from the memory than favourable ones."

While in Nicaragua, I had none of Orwell's capacity to stare down uncomfortable facts. Nor was I wise or honest 
Michael Johns

enough to follow Darwin's rule of writing down everything that ran counter to my ideas. But I did manage to see, if unwittingly, just enough of the Sandinista revolution to get my first lesson in realism. 
The Education of a Radical 
THIS PAGE INTENTIONALLY LEFT BLANK 